\title{
OBSERVATION OF AN AMERICAN MINK CLIMBING A TREE
}

\section{SERGE LARIVIĖRE, 829 Main Street, Saskatoon, SK. S7H OK2}

Members of the family Mustelidae such as American Marten, Fisher, Wolverine, and weasels are known to climb trees. ${ }^{1}$ Jackson ${ }^{2}$ believed that mink "may rarely climb small trees to a height of about ten feet." Similarly, Dekker ${ }^{3}$ reported tree climbing by an American Mink chased across a pasture. However, accounts of this behaviour remain rare in the literature. ${ }^{4}$ I herein report an eyewitness account of this behaviour for a wild American Mink inhabiting the parkland region of central Saskatchewan.

On 25 April 1993, while live-trapping Striped Skunks, I captured an American Mink in a live-trap located $24 \mathrm{~m}$ from open water in the forested perimeter of a permanent wetland 10 $\mathrm{km}$ northwest of Krydor. Upon release from the trap (6:50 a.m. CST), the animal ran $1 \mathrm{~m}$ to the nearest tree, a balsam poplar of $17 \mathrm{~cm}$ of diameter, and climbed to a height of $2.5 \mathrm{~m}$. After staring and hissing for about 5 seconds the animal climbed down $30 \mathrm{~cm}$ and jumped to another balsam poplar (16 $\mathrm{cm}$ in diameter) $1.5 \mathrm{~m}$ away. Still hissing, it climbed down head first to $1.5 \mathrm{~m}$ off the ground and leaped, landing approximately $1 \mathrm{~m}$ from the base of the tree. It then ran towards open water and disappeared in the surrounding dense vegetation of cattails, willows, and red osier dogwood. The observation lasted less than 60 seconds.

It is surprising that, with open water within $24 \mathrm{~m}$ of the site, the mink chose to climb a tree instead of simply fleeing towards the open water. Tree climbing may be used as an escape strategy by American Mink when threatened by terrestrial predators, especially when other escape strategies such as diving or hiding are not possible.

In prairie environments, American Mink usually rest in muskrat burrows, ground squirrel burrows, rockpiles, brushpiles, culverts and stands of emergent vegetation. ${ }^{5}$ Considering the ease with which the American Mink climbed the tree, it is possible that resting in trees may occur under certain circumstances. However, the extent to which tree climbing is used by American mink for escaping predation, or for other activities, remains unknown.

1. NOVAK, M., J.A. BAKER, M.E. OBBARD, and B. MALLOCH (eds.). 1987. Wild furbearer management and conservation in North America. Ontario Ministry of Natural Resources, Toronto. $1150 \mathrm{pp}$.

2. JACKSON, H.H.T. 1961. Mammals of Wisconsin. Univ. of Wisconsin Press, Madison. 504 pp.

3. DEKKER, D. 1993. Tree-climbing by long-tailed weasel: an anti-predator strategy? Blue Jay 51:179-180.

4. DUNSTONE, N. 1993. The mink. T. \& A.D. Poyser Natural History, London, U.K. 232 pp.

5. ARNOLD, T.W., and E.K. FRITZELL. 1989. Spring and summer prey remains collected from male mink dens in southwestern Manitoba. Prairie Nat. 21:189-192. 